\title{
Effect of chronic ammonia exposure on growth of European seabass (Dicentrarchus labrax) juveniles
}

\author{
G. Lemarié ${ }^{a}$, A. Dosdat ${ }^{a}{ }^{a}$, D. Covès ${ }^{a}$, G. Dutto ${ }^{a}$, E. Gasset ${ }^{a}$ and J. Person-Le Ruyet ${ }^{b}$ \\ a IFREMER, Station Expérimentale d'Aquaculture, 34250, Palavas les Flots, France \\ b IFREMER, Centre de Brest, B.P. 70, 29280, Plouzané, France \\ *: Antoine.Dosdat@ifremer.fr
}

\begin{abstract}
Chronic effects of ammonia were studied in juvenile seabass, Dicentrarchus labrax (mean WEIGHT=11 g), exposed for 63 days to eight stable ammonia concentrations, ranging from 0.24 to $0.90 \mathrm{mg} \mathrm{I}-1$ unionised ammonia nitrogen (UIA-N), respectively, from 6.1 to $22.3 \mathrm{mg} \mathrm{I}-1$ total ammonia nitrogen (TA-N). Temperature $\left(21.8^{\circ} \mathrm{C}\right), \mathrm{pH}(8.0)$, salinity (37.0 ppt), and oxygen concentration (over $80 \%$ saturation at the outlet) were maintained constant. Fish were fed using a self-feeder device, and they were starved during the last 8 days. Mortality of 28.9 and $42.6 \%$ occurred within the first 8 days at the two highest UIA-N concentrations, respectively, 0.90 and $0.88 \mathrm{mg} \mathrm{I}-1$. From days 0 to 55 , a 1.8fold increase in weight gain was observed under the 0.90-mg I-1 UIA-N condition, compared to a 3.4fold increase in the control. Weight gains were negatively correlated to ambient ammonia concentrations. Weight loss, or a transient period of growth stagnation, was observed from the onset of ammonia exposure to day 13 in seabass exposed to concentrations above $0.43 \mathrm{mg} \mathrm{I-1} \mathrm{UIA-N}$. After day 13 , weight gains were observed in all groups, indicating that the fish were able to adapt to increased ambient ammonia concentrations over time. By the end of the experiment, plasma ammonia levels were positively related to ambient ammonia concentrations, and oxygen consumption recorded in fasting fish was significantly dependent on ammonia concentrations. In seabass juveniles, the 0.26mg I-1 UIA-N concentration, under an average $\mathrm{pH}$ of 8.0 , can be considered as a safe long-term limit conditions in seawater.
\end{abstract}

Keywords: Ammonia; Chronic toxicity; Seabass; Growth; Plasma ammonia 


\section{Introduction}

Ammonia and urea are the two main nitrogenous products excreted by teleost fish (Forster and Goldstein, 1969), with ammonia usually representing 75 to $90 \%$ of nitrogenous excretion (Handy and Poxton, 1993). Ammonia is mainly excreted as the un-ionised form $\mathrm{NH}_{3}$ (UIA). In seawater, $\mathrm{NH}_{3}$ ionises to form $\mathrm{NH}_{4}{ }^{+}$. The relative proportion of the two forms depends upon $\mathrm{pH}$, temperature and, to a lesser extent, salinity (Whitfield, 1974; Bower and Bidwell, 1978). In seawater, ammonia is measured as total ammonia nitrogen (TAN), which represents the sum of UIA-N and $\mathrm{NH}_{4}{ }^{+}-\mathrm{N}$. The $\mathrm{NH}_{3}$ molecule is non-polar and readily soluble in lipids. It is 300 to 400 times more toxic than $\mathrm{NH}_{4}{ }^{+}$(Thurston et al., 1981; Haywood, 1983). Under intensive rearing conditions, and particularly when effluent water is re-used, ambient ammonia concentrations may reach levels that limit fish survival and growth (Haywood, 1983).

The acute and chronic toxicities of ammonia have been extensively reviewed for freshwater species (Ruffier et al., 1981; Haywood, 1983; Russo and Thurston, 1991; Handy and Poxton, 1993 ; Tomasso, 1994) but ammonia toxicity data for marine fish species or salmonids in sea water are relatively scarce (Alderson, 1979; Wajsbrot et al.,1993; Tudor et al., 1994; Person-Le Ruyet et al., 1995, 1997a, b; Fivelstad et al., 1995). Further, the chronic effects of exposure to ammonia in seawater have rarely been examined (Person-Le Ruyet and Bœuf, 1998). However, « safe levels » for growth, usually extrapolated from LC50 data, are reported to range from 0.05 to $0.2 \mathrm{mg} \mathrm{l}^{-1}$ UIA-N (Ruffier et al., 1981, Handy and Poxton, 1993), depending on species, age and environment (oxygen concentration, pH). Lethal concentration for $50 \%$ of the population 
(96-h LC50) have been reported to be $1.7 \mathrm{mg} \mathrm{l}^{-1}$ UIA-N (40.0 $\mathrm{mg} \mathrm{l}^{-1} \mathrm{TAN}$ ) in seabass juvenile (Person-Le Ruyet et al., 1995).

Seabass farming in sea cages and land-based systems is developing rapidly in the Mediterranean region, with production increasing from $4700 \mathrm{mt}$ in 1991 to $23000 \mathrm{mt}$ in 1997, to some $50000 \mathrm{mt}$ in 2000 (Paquotte P., comm. pers.). For economic and environmental reasons, culture systems using recirculating water are being developed, and as a result, there is a need to define the environmental quality standards required for fish growth. The purpose of this study is to provide information about the chronic effects of ammonia exposure on survival and growth of seabass juvenile.

\section{Materials and methods}

\section{Fish and rearing conditions}

Seabass were reared at Ifremer Station in Palavas from eggs to day 132 in semi-closed systems (Covès et al., 1991). Fish were graded and those within the weight range (4.0 \pm 1.4 g) were randomly distributed (230 fish per tank) amongst 9 circular tanks (effective volume $1 \mathrm{~m}^{3}$ ) in a sound-proof facility. The fish were acclimated to the rearing conditions for 41 days prior the experiment. The experiment then lasted 63 consecutive days. Fish were fed from day 1 to 55 using expanded pellets (54.3\% proteins, $15.3 \%$ crude fat), using a self-demand system described by Boujard et al. (1992). When the fish activated a rod positioned below the water surface, an electric pulse was generated to stimulate an electric feeder that delivers a predetermined amount of feed (1.5 to $2.0 \mathrm{~g}$ ). Every day, the feeding system was turn off between 9:00 h and 10:00 h in 
order to replenish the feeders and to check for the presence of uneaten pellets collected in a sedimentation trap located at the outlet of each tank. From day 56 to day 63, fish were starved. Tanks were supplied with running sea water, sand-filtered at $15 \mu \mathrm{m}$, UV sterilised, heated, degassed in a packed column and dispatched to the tanks by gravity. Flow rate was fixed at $1 \mathrm{~m}^{3}$ $\mathrm{h}^{-1}$ (accuracy of the flow-meter : $\pm 0.05 \mathrm{~m}^{3} \mathrm{~h}^{-1}$ ) in order to maintain oxygen saturation systematically above $80 \%$ and to provide self-cleaning of the tank. Temperature was maintained at $21.80 \pm 0.15{ }^{\circ} \mathrm{C}$ (mean \pm standard deviation (SD)) using a heat-exchanger and checked hourly. Salinity (37.0 $\pm 2.5 \mathrm{ppt})$ was checked once a day, and $\mathrm{pH}(7.99 \pm 0.14)$ once a day. Light intensity at the water surface was 250 lux, and the photoperiod was maintained at $16 \mathrm{~h}$ light - 8h dark including a 30 min artificial dawn and dusk, using incandescent lamp (OSRAM Decor Silver E27).

\section{Experimental design}

Eight different ammonia solutions of eight different TAN concentrations, ranging 14.4-57.7 $\mathrm{g}^{-1}$ TAN, were delivered in the inlet of eight tanks from day 1 to day 63, using a peristaltic pump (8 channels, flow rate around $5 \mathrm{ml} \mathrm{min}^{-1}$ ). These concentrated solutions were obtained by dissolving 61 to $245 \mathrm{~g} \mathrm{l}^{-1}$ ammonium chloride powder $\left(\mathrm{NH}_{4} \mathrm{Cl}\right.$, BASF® $99.5 \%$ purity) in tap water. Inputs of ammonia were calculated to obtain a range of eight concentrations, from 10 to $40 \%$ of the 96-h LC50s reported for seabass juvenile by Person-Le Ruyet et al. (1995), in the rearing tanks. Due to the preciseness of the peristaltic pump, the range of the concentrations failed to demonstrate equal steps, but every flow rate was constant with time. A ninth tank (control) did not receive ammonia solution. The ambient ammonia concentration within each 
tank was checked daily in a 24h-pooled sample of water, obtained from the effluent water and poured in a 21 bottle where $5 \mathrm{ml}$ of 99.5\% chloroform were added for stabilisation (Dosdat et al., 1992). The TAN concentration was then determined by the indophenol method (Bower and Holm-Hansen, 1980), using a Technicon Analyser ${ }^{\circledR}$. For each tank, the mean TAN concentrations \pm SD were calculated from daily data. The $\mathrm{pH}$ was measured at the outlet using a Tacussel PHN81 ${ }^{\circledR}$ pH-meter, coupled with a Tacussel TC100 ${ }^{\circledR}$ probe containing a saturated solution of $\mathrm{KCl} / \mathrm{AgCl}$ (Tacussel $\mathrm{KS} 120{ }^{\circledR}$ ) and an Ag/AgCl reference electrode (Johansson and Wedborg, 1980). UIA-N concentrations were calculated from TAN according to $\mathrm{pH}$, temperature and salinity, using the equation of Johansson and Wedborg (1980). Therefore, the percentage of UIA-N to TAN was given by the following equation :

$$
\% \text { NH3 }=100 /\left[1+10^{\left(\operatorname{logK}-p_{1}\right)}\right]
$$

with

$$
\log K_{1}=-0.467+0.00113 \times \mathrm{S}+2.887 .9 \times \mathrm{T}^{-1}
$$

where $\mathrm{K}_{1}$ is the dissociation constant, $\mathrm{S}\left(\right.$ in $\mathrm{g} \mathrm{l}^{-1}$ ) the salinity and $\mathrm{T}$ the temperature $\left({ }^{\circ} \mathrm{K}\right.$ )

In every tanks, at day $0,13,27,41$ and 55 , the fish, fasted for $24 \mathrm{~h}$, were anaesthetised (using a solution containing $150 \mu \mathrm{l} \mathrm{l}^{-1}$, ethylene-glycol-monophenyl-ether), counted and 50 of them were randomly collected and individually weighed to the nearest $0.01 \mathrm{~g}$. In order to avoid a lowering of the oxygen concentration due to increasing biomass, stocking density was reduced on day 27 by removing at random 130 fish per tank. Fish were weighed again to establish an initial weight. Mortality was counted daily.

The mean wet weights \pm standard deviation were calculated as the arithmetic mean from the samples of 50 fishes. The average individual weight gain at day 55 was calculated as $\mathrm{Wf}-\mathrm{Wi}$, 
where Wf is the final mean wet weight $(n=50)$ at day 55 and Wi is the initial mean wet weight $(n=50)$.

Oxygen concentrations of inlet and outlet water from each tank was monitored using the methodology described by Lemarié et al. (1992). A part of inflowing and outflowing water was diverted through solenoid valves to a measure chamber where oxygen concentration was measured using a Ysi $58^{\circledR}$ oxymeter. Oxygen data were recorded on a data logger (GrantSquirrel $^{\circledR}$ SQ16-4V-1D). Recording, opening and closing of each solenoid valve were managed by an automatic controller device. Oxygen concentrations were measured every $40 \mathrm{~min}$. during 5 consecutive days, (from day 58 to 63 ) on starved fish in the control, $0.26,0.43,0.64$, and 0.88 mg $\mathrm{l}^{-1}$ UIA-N conditions. Oxygen uptake $\left(\mathrm{MO}_{2}\right)$ in each tank was calculated as :

$$
\mathrm{MO}_{2}\left(\mathrm{mg} \mathrm{kg}^{-1} \mathrm{~h}^{-1}\right)=\left(\left[\mathrm{O}_{2}\right] \text { outlet }-\left[\mathrm{O}_{2}\right] \text { intlet }\right) \times \text { flow rate }\left(\mathrm{l} \mathrm{h}^{-1}\right) \times \text { fish biomass }{ }^{-1}(\mathrm{~kg})
$$

In the same tanks, on day 57 blood samples were collected, on 14 individuals per tanks, from vessels at the caudal peduncle using free-ammonium salt heparinized syringe, pooled in pairs to get enough blood and immediately centrifuged. Plasma TAN contents were determined within one hour using the enzymatic kit Sigma Diagnostic UV-170 ${ }^{\circledR}$.

Experimental data on growth at the end of each period were processed by one-way analysis of variance (ANOVA). Concerning data on water quality and triggering activity, possible differences among treatments were tested by repeated measures ANOVA (Zar, 1984). Pairwise comparisons between the means were made using the Student-Newman-Keuls (SNK) test. The accepted level of significance was $\mathrm{P}<0.05$. 


\section{Results}

Environmental conditions :

The environmental conditions within the rearing tanks (temperature, salinity, oxygen concentration, $\mathrm{pH}$ ) were stable. The variation coefficients (CV\%, Table 1) of the eight ambient TAN concentrations tested were low, ranging from 11 to $19 \%$. The $\mathrm{pH}$ was stable in all the treatments, ranging from 7.89 to 8.13 during the whole experiment. This meant a good correlation between the UIA-N fraction and TAN. Under the experimental conditions, the average ambient UIA-N to TAN ratio was $4.0 \%$. Repeated measures one way ANOVA on oxygen levels in the 9 tanks during the 55 first days demonstrated that there were no significative difference among the treatments $(\mathrm{F}(432 ; 8)=0.543, \mathrm{n}=55)$. 
Table 1 - Ammonia concentrations (mean $\pm \mathrm{SD}$, $\mathrm{mg} \mathrm{l}^{-1}$ ) in seawater during the 63 days experiment. Values bearing common superscript in the same column are not significantly different $(\mathrm{P}<0.05)$.

\begin{tabular}{ccccc}
\hline \multirow{2}{*}{ Tank } & Number & \multicolumn{2}{c}{ Measured TAN $\left(\mathrm{mg} \mathrm{l}^{-1}\right)$} & Calculated UIA-N $\left(\mathrm{mg} \mathrm{l}^{-1}\right)$ \\
\cline { 3 - 5 } & & mean \pm SD & C.V (\%) & mean \pm SD \\
\hline Control & 63 & $0.4 \pm 0.1^{\mathrm{a}}$ & 18.9 & $0.01 \pm 0.0^{\mathrm{a}}$ \\
C1 & 63 & $6.1 \pm 0.8^{\mathrm{b}}$ & 13.5 & $0.24 \pm 0.04^{\mathrm{b}}$ \\
C2 & 63 & $6.6 \pm 0.7^{\mathrm{c}}$ & 10.7 & $0.26 \pm 0.04^{\mathrm{c}}$ \\
C3 & 63 & $10.6 \pm 1.2^{\mathrm{d}}$ & 11.3 & $0.43 \pm 0.05^{\mathrm{d}}$ \\
C4 & 63 & $13.3 \pm 2.6^{\mathrm{e}}$ & 19.3 & $0.53 \pm 0.10^{\mathrm{e}}$ \\
C5 & 63 & $15.9 \pm 1.8^{\mathrm{f}}$ & 11.8 & $0.64 \pm 0.08^{\mathrm{f}}$ \\
C6 & 63 & $17.7 \pm 3.0^{\mathrm{g}}$ & 17.0 & $0.71 \pm 0.12^{\mathrm{g}}$ \\
C7 & 63 & $21.7 \pm 2.3^{\mathrm{h}}$ & 11.1 & $0.88 \pm 0.10^{\mathrm{h}}$ \\
C8 & 63 & $22.3 \pm 3.1^{\mathrm{h}}$ & 14.0 & $0.90 \pm 0.13^{\mathrm{h}}$ \\
\hline
\end{tabular}

\section{Behaviour and mortality}

Changes in the swimming behaviour (disorientation and erratic swimming), in gill ventilation, and in the colour of fish (darkened skin) were observed within two hours after addition of ammonia in the rearing tanks. They were noticed until 15 days of ammonia exposure for the two highest concentrations. This observation was correlated with the feeding triggering activity (i.e. the number of actuations on the rod), which was significantly different (repeated measures one way ANOVA; $\mathrm{F}(72,8)=14.25 ; \mathrm{n}=12$ ) among the treatments from day 1 to 12 . The number of actuations was the highest in the $0.43,0.53$ and $0.64 \mathrm{mg} \mathrm{l}^{-1}$ UIA-N conditions (Table 2). It decreased for the two highest concentrations. This typical observation was still perceptible at the end of the feeding period (day 41-55; Table 2). 
No mortality was observed from control up to $0.71 \mathrm{mg} \mathrm{l}^{-1}$ UIA-N (17.7 $\mathrm{mg} \mathrm{l}^{-1}$ TAN) concentrations. In the 0.90 and $0.88 \mathrm{mg} \mathrm{l}^{-1}$ UIA-N groups, respectively 29 and $43 \%$ of the fish died between day 0 and 8 . No mortality was observed after (Figure 1) .

Table 2 - Average daily number of actuations (mean \pm SD) by fish under various ambient ammonia conditions. Values bearing common superscript in the same row are not significantly different $(\mathrm{P}<0.05)$.

\begin{tabular}{cccccccccc}
\hline & Control & C1 & C2 & C3 & C4 & C5 & C6 & C7 & C8 \\
\hline Day 1-12 & 72.1 & 51.5 & 59.9 & 123.1 & 129.2 & 158.6 & 120.2 & 114.2 & 68.7 \\
& $\pm 18.6^{\mathrm{a}}$ & $\pm 8.7^{\mathrm{a}}$ & $15.5^{\mathrm{a}}$ & $\pm 21.9^{\mathrm{b}}$ & $\pm 48.0^{\mathrm{b}}$ & $\pm 41.6^{\mathrm{b}}$ & $\pm 19.3^{\mathrm{b}}$ & $\pm 25.5^{\mathrm{b}}$ & $\pm 16.4^{\mathrm{a}}$ \\
\hline Day 41-55 & 46.9 & 47.2 & 55.3 & 110.6 & 179.1 & 124.8 & 91.6 & 144.7 & 73.7 \\
& $\pm 14.6^{\mathrm{a}}$ & $\pm 19.1^{\mathrm{a}}$ & $31.8^{\mathrm{a}}$ & $\pm 24.5^{\mathrm{c}}$ & $\pm 34.8^{\mathrm{e}}$ & $\pm 18.7^{\mathrm{c}}$ & $\pm 12.8^{\mathrm{b}}$ & $\pm 14.3^{\mathrm{d}}$ & $\pm 25.6^{\mathrm{b}}$ \\
\hline
\end{tabular}

Figure 1 - Cumulative survival rate during the first 10 days in the three tanks where mortality occurred.

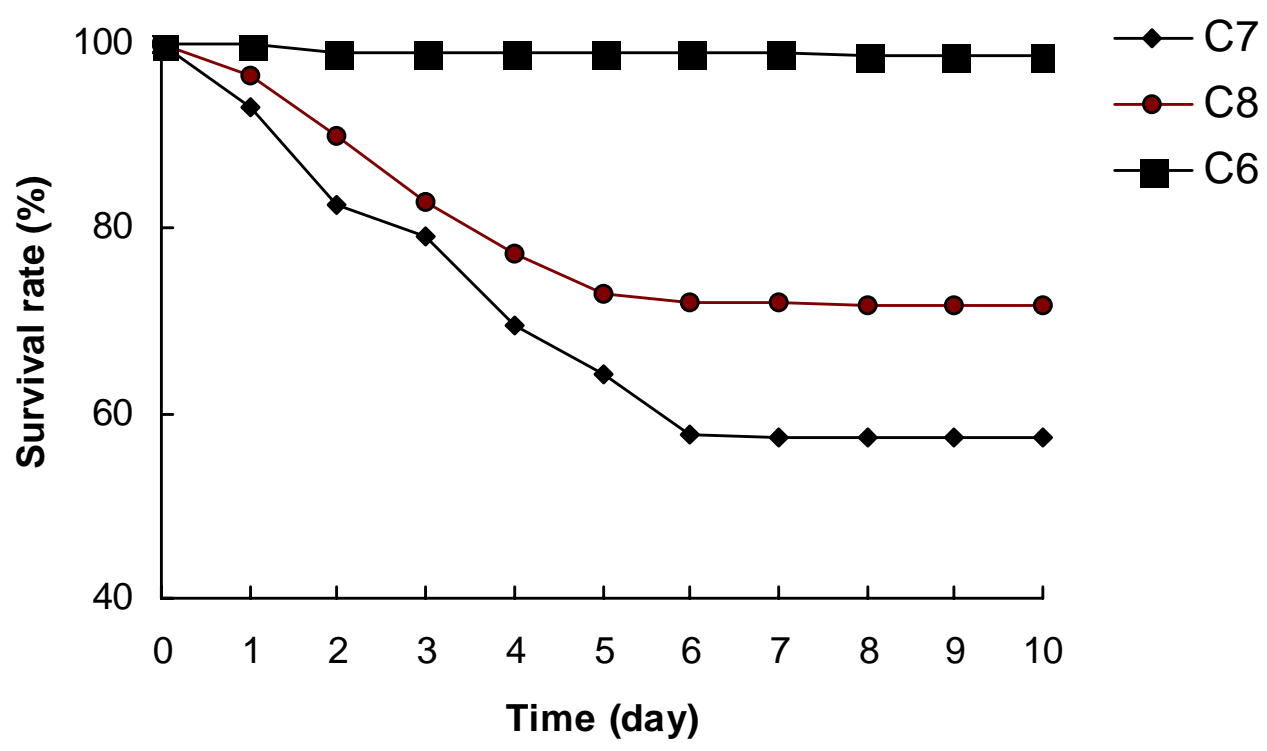


Fish growth

In all groups of fish exposed to ammonia, except for the two lower concentrations, marked effects on growth were observed (Table 3). At day 13, weight increase was significantly lower in fish exposed to 0.24 and $0.26 \mathrm{mg} \mathrm{l}^{-1}$ UIA-N than in the control. Fish growth was stopped in the 0.43, 0.53 and $0.64 \mathrm{mg} \mathrm{l}^{-1}$ UIA-N groups, while fish lost weight when ammonia concentration was over $0.71 \mathrm{mg} \mathrm{l}^{-1}$ UIA-N. From day 27, individual weight gains were observed in all fish groups. From day 41, fish submitted to the two lowest concentrations where not significantly different from the control. Over the 55-day feeding period, mean weights increased by 3.4 fold in the controls and only by 1.8 in the highest ammonia concentrations tested. Figure 2 shows the weight gain, expressed as a percentage of the weight gain by the control fish, in relation with ammonia concentration in seawater. This relative growth performance index was linearly and negatively correlated to the ammonia concentrations, and can be described by the equation:

$$
y=-83.03 x+102.1 \quad r^{2}=0.97
$$

where $\mathrm{y}$ is the $\%$ of growth compared to the control and $\mathrm{x}$ is the UIA-N concentration in $\mathrm{mg} \mathrm{l}^{-1}$. The weight increase at day 55 was $90 \%$ of the control fish at $0.14 \mathrm{mg} \mathrm{l}^{-1}$ UIA-N (3.4 $\mathrm{mg} \mathrm{l}^{-1}$ TAN) and $50 \%$ at $0.62 \mathrm{mg} \mathrm{l}^{-1}$ UIA-N (15.3 mg.l ${ }^{-1}$ TAN).

During the first 55 days, the average daily food intake for the two lower concentrations (respectively 2.2 and $2.6 \%$ of the standing biomass) was similar to the control (2.5\%). Due to high food spillage, estimation of uneaten pellets was not possible in fish submitted to higher TAN concentrations. Apparent food delivery for the higher concentration conditions did not represent the actual intake by the fish. 
Table 3 - Fish weights in grammes (mean \pm SD, $n=50$ ) of seabass juveniles exposed to ammonia in seawater at different sampling days. Values in the same column marked with a common superscript are not significantly different $(\mathrm{P}<0.05)$.

\begin{tabular}{|c|c|c|c|c|c|c|}
\hline & UIA-N (mg l $\left.{ }^{-1}\right)$ & day 0 & day 13 & day 27 & day 41 & day 55 \\
\hline Control & 0.01 & $12.1 \pm 2.8$ & $16.6 \pm 4.3^{\mathrm{a}}$ & $24.5 \pm 6.3^{\mathrm{a}}$ & $31.6 \pm 8.3^{\mathrm{a}}$ & $40.1 \pm 9.3^{\mathrm{a}}$ \\
\hline C1 & 0.24 & $10.6 \pm 2.4$ & $15.4 \pm 4.1^{\mathrm{b}}$ & $22.1 \pm 6.1^{\mathrm{b}}$ & $28.1 \pm 7.6^{\mathrm{a}}$ & $37.0 \pm 9.2^{\mathrm{a}}$ \\
\hline $\mathrm{C} 2$ & 0.26 & $11.2 \pm 2.5$ & $14.8 \pm 3.7^{\mathrm{b}}$ & $20.9 \pm 5.6^{b}$ & $29.8 \pm 8.0^{\mathrm{a}}$ & $34.1 \pm 8.8^{\mathrm{a}}$ \\
\hline C3 & 0.43 & $11.2 \pm 3.0$ & $11.4 \pm 2.9^{c}$ & $16.3 \pm 4.5^{c}$ & $23.5 \pm 7.3^{\mathrm{b}}$ & $29.9 \pm 8.3^{b}$ \\
\hline $\mathrm{C} 4$ & 0.53 & $10.9 \pm 2.6$ & $11.2 \pm 3.0^{c}$ & $15.6 \pm 3.7^{c}$ & $20.9 \pm 5.4^{\mathrm{b}}$ & $27.5 \pm 7.5^{b}$ \\
\hline C5 & 0.64 & $12.0 \pm 2.4$ & $11.2 \pm 2.3^{\mathrm{c}}$ & $14.9 \pm 4.2^{c}$ & $17.6 \pm 5.5^{d}$ & $24.8 \pm 5.7^{c}$ \\
\hline C6 & 0.71 & $12.1 \pm 3.1$ & $10.4 \pm 2.9^{c}$ & $13.8 \pm 3.5^{\mathrm{d}}$ & $19.3 \pm 4.9^{c}$ & $24.0 \pm 5.8^{c}$ \\
\hline C7 & 0.88 & $11.6 \pm 3.3$ & $9.9 \pm 2.8^{\mathrm{c}}$ & $12.3 \pm 3.2^{\mathrm{d}}$ & $17.3 \pm 3.8^{d}$ & $20.7 \pm 5.3^{d}$ \\
\hline C8 & 0.90 & $11.4 \pm 2.7$ & $9.9 \pm 2.3^{c}$ & $12.7 \pm 3.0^{\mathrm{d}}$ & $17.5 \pm 3.5^{\mathrm{d}}$ & $20.6 \pm 4.7^{\mathrm{d}}$ \\
\hline \multicolumn{2}{|c|}{$F(441,8)$} & 1.98 & 32.04 & 45.47 & 40.55 & 41.17 \\
\hline
\end{tabular}

Fig. 2. Weight gain expressed as a \% of the weight gain of the control fish in relation with ambient ammonia concentration in seawater on the 55-day trial.

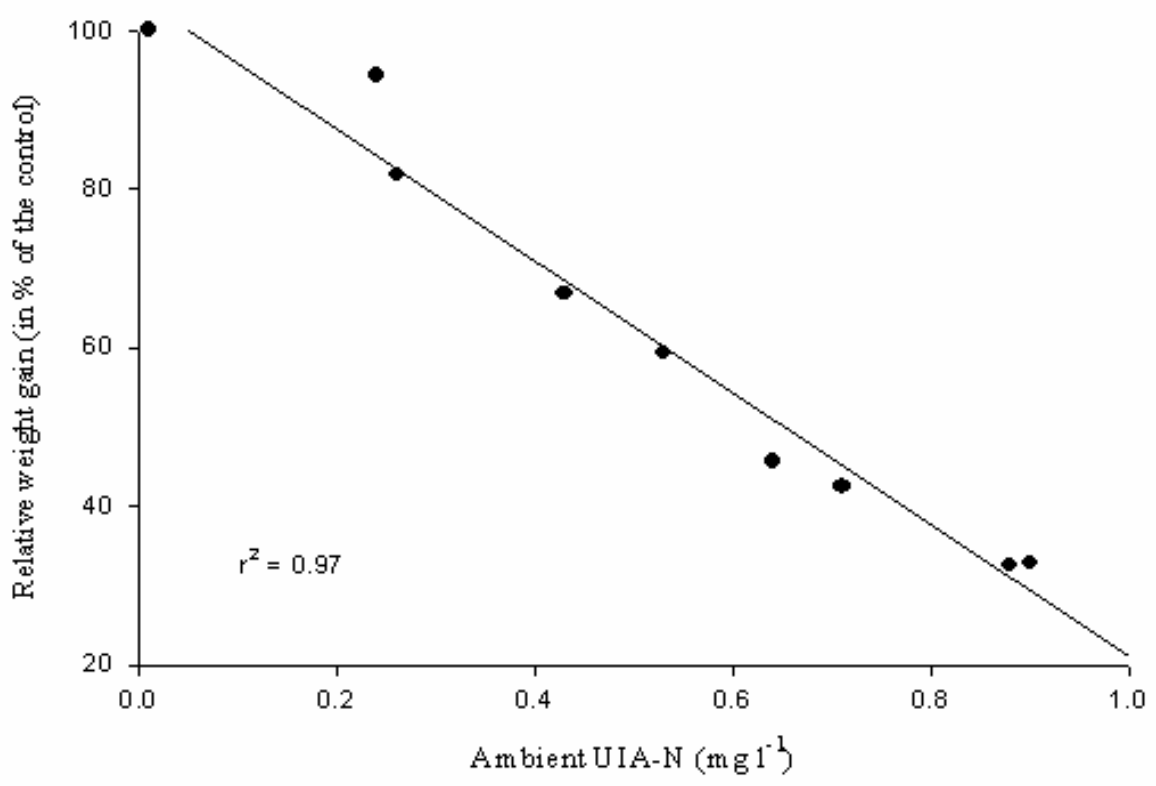


Oxygen uptake and plasma ammonia concentration

Oxygen consumption by fish starved for 5 to 10 days ranged from $205 \mathrm{mg} \mathrm{O}_{2} \mathrm{~kg}^{-1} \mathrm{~h}^{-1}$ for the control group to $368 \mathrm{mg} \mathrm{O}_{2} \mathrm{~kg}^{-1} \mathrm{~h}^{-1}$ for the $0.88 \mathrm{mg} \mathrm{l}^{-1}$ UIA-N group. It was positively correlated to ammonia concentrations as shown in Figure 3. The relation can be described by the following equation :

$$
y=199.7 x+191.1 \quad r^{2}=0.93
$$

where $y$ is the oxygen consumption ( $\mathrm{mg} \mathrm{kg}^{-1} \mathrm{~h}^{-1}$ ) and $\mathrm{x}$ the UIA-N concentration $\left(\mathrm{mg} \mathrm{l}^{-1}\right)$.

In seabass, acclimated to ammonia for 57 days and starved for 2 days, plasma TAN was also dependant on ambient ammonia concentration as shown in Figure 4 according to the following equation :

$$
y=0.48 x+3.32 \quad r^{2}=0.97
$$

where $\mathrm{y}$ is the plasma TAN concentration $\left(\mathrm{mg} \mathrm{l}^{-1}\right)$ and $\mathrm{x}$ the TAN concentration in seawater(mg $\left.\mathrm{l}^{-1}\right)$ 
Fig. 3. Oxygen uptake in relation with ambient ammonia concentration in seawater. Vertical bars represent the standard deviation of the mean.

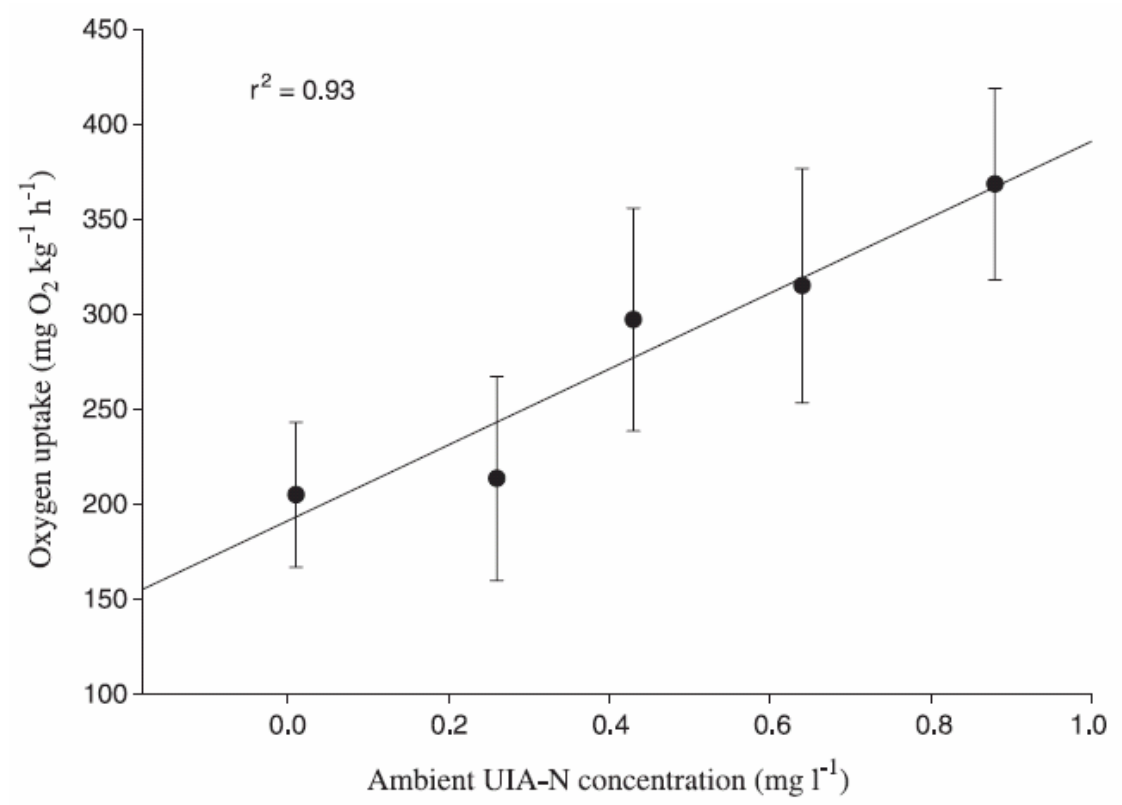

Fig. 4. Plasma TA-N in relation with ambient ammonia concentration in seawater. Vertical bars represents standard deviation of the mean.

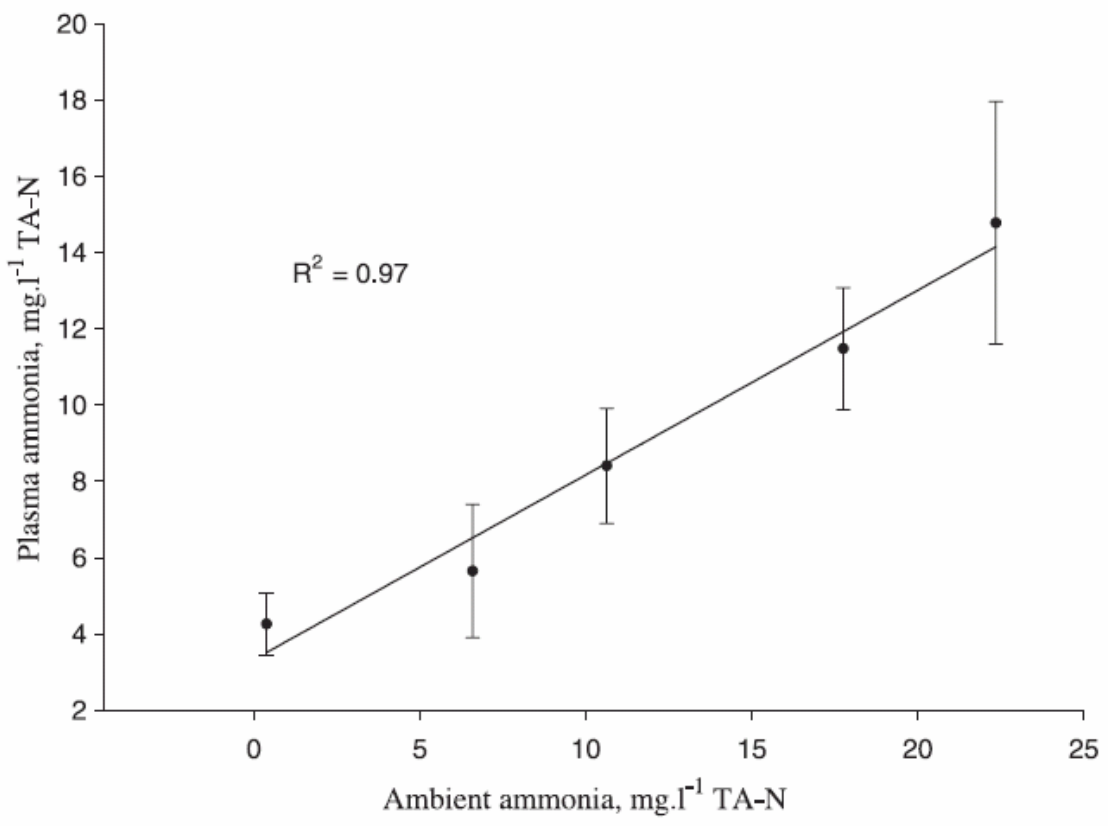




\section{Discussion}

This study presents results concerning the long-term effects of ambient ammonia on juvenile seabass and supplements acute toxicity tests performed on the same species (Tudor et al., 1994, Person-Le Ruyet et al., 1995). Environmental parameters (pH, dissolved oxygen, temperature and salinity) were stable and were similar among treatments and were not limiting for growth (Lemarié et al., 2000). Thus, the effects we observed on growth were attributed to ammonia, which varied among treatments. The growth of the fish in the control tank was in the range of values reported recently in the literature (Quemener et al., 1999; Peres and Oliva-Teles, 1999; Pichavant et al., 2001).

The experiment confirmed that ammonia is stressful for the fish even at low concentrations. The effect of ammonia is immediate, linear and dose dependant. Person-Le Ruyet et al. (1998) have shown that ammonia entered fish within 15 minutes of exposure. The observed effects on the changes in behaviour were similar to those reviewed by Haywood (1983). They were associated with erratic actuations on self-feeders and with an increase in the oxygen consumption. These feeder actuations were not a consequence of feeding activity, but of abnormal swimming at the surface. They were the result of the build up of ammonia in the blood and other tissues (brain, liver, muscle) which has negative effects on synaptic connections of the central nervous system and the NMDA (N-Methyl-D-aspartic Acid) receptor activity (Russo and Thurston, 1991; Tomasso, 1994; Montfort et al., 2000).

Survival was $100 \%$ from the control to the $0.71 \mathrm{mg} \mathrm{l}^{-1}$ UIA-N level, which represents $42 \%$ of the 96-h LC50 (1.7 mg l-1 UIA-N) in the species (Person-Le Ruyet et al., 1995). This maximum 
ammonia level for no mortality was higher than in turbot juveniles (Person-Le Ruyet et al., 1997b). Mortality was recorded for the highest ammonia concentrations : 43\% of the fish died after 8 day exposure at $0.88 \mathrm{mg} \mathrm{l}^{-1}$ UIA-N, which can be considered as a rough estimate of the 8 day LC50. Comparison of various LC50 estimates on seabass, seabream, turbot and some freshwater species is given in Table 4. From our study, juvenile seabass appeared more sensitive than turbot, and comparable to seabream, as it was predicted by Person-Le Ruyet et al. (1995).

Table 4 - Comparison of various ammonia toxicity levels in some fish species.

\begin{tabular}{lllcl}
\hline & Species & TAN $\left(\mathrm{mg} \mathrm{l}^{-1}\right)$ & UIA-N $\left(\mathrm{mg} \mathrm{l}^{-1}\right)$ & Authors \\
\hline 4-day LC50 & Seabass & 40 & 1.7 & Person-Le Ruyet et al., 1995 \\
4-day LC50 & Seabream & 57 & 2.5 & Person-Le Ruyet et al., 1995 \\
4-day LC50 & Turbot & 59 & 2.6 & Person-Le Ruyet et al., 1995 \\
4-day LC50 & Catfish & 45 & 1.6 & Colt and Tchobanoglous, 1978 \\
4-day LC50 & Rainbow trout & 22 & $0.3-0.6$ & Haywood, 1983 \\
8-day LC50 & Seabass & $>22.3$ & $>0.9$ & This study \\
20-day LC50 & Seabream & 15.7 & 0.89 & Wajsbrot et al., 1993 \\
28-day LC50 & Turbot & 38 & 1 & Person-Le Ruyet and Bœuf, 1998 \\
& & & & \\
20-day EC50 & Seabream & 15.7 & 0.89 & Wajsbrot et al., 1993 \\
28-day EC50 & Turbot & $17-19$ & $0.50-0.65$ & Person-Le Ruyet et al., 1998 \\
55-day EC50 & Turbot & $17-21$ & $0.60-0.75$ & Person-Le Ruyet et al.,1998 \\
55-day EC50 & Seabass & 22 & 0.9 & This study \\
\hline
\end{tabular}

LC50: lethal concentration for $50 \%$ of the population.

EC50 : concentration reducing growth by $50 \%$.

At day 27, a weight gain is recorded in all the treatments, indicating that the fish globally adapted to their environment, and that the physiological disturbances were partly reversed after day 13 (Person-Le Ruyet et al.,1998). The physiological processes were then sufficiently re- 
organised to enable growth. Physiological effects include mostly higher activities of glutamine synthetase, which transforms glutamate (a highly potent excitatory neurotransmitter) into glutamine by adding a $\mathrm{NH}_{3}$ molecule, in the brain in non-ureotelic fish (Wang and Walsh, 2000). Detoxification of ammonia to urea is the other pathway that can be utilised by many fish species (Wood 1993). After 27 days of ammonia exposure, acclimated seabass expressed a lower growth than control fish at all ammonia levels. At that time, in all the treatments, the fish could not compensate for the initial growth delay recorded at day 13.

Statistically, after 55 days, the growth performances of seabass juveniles were not affected by the two lowest ammonia concentrations, i.e. 0.24 and $0.26 \mathrm{mg} \mathrm{l}^{-1}$ UIA-N, (respectively 6.1 and 6.6 mg. $\mathrm{l}^{-1}$ TAN), even if the fish expressed respectively 94 and $82 \%$ of the growth of the control fish. In that sense, some compensatory growth might have occurred between day 27 and day 55 . Behavioral and physiological disturbances were still perceptible by the end of the experiment as shown by triggering activity, increased oxygen uptake and plasma ammonia accumulation. The concentration of no-observable effect have been reported to be $0.11-0.18 \mathrm{mg} \mathrm{l}^{-1}$ UIA-N in turbot juveniles (Person-Le Ruyet and Bœuf, 1998) and $0.27 \mathrm{mg} \mathrm{l}^{-1}$ UIA-N in seabream juveniles (Wajsbrot et al., 1993). These values are closed to the 0.24-0.26 $\mathrm{mg} \mathrm{l}^{-1}$ UIA-N we observed in seabass, which represents $16 \%$ of the $96-\mathrm{h}$ LC50. These data suggest that there are no major differences in the long-term sensitivity to ammonia among marine species, and that their longterm sensitivity is lower than in most salmonids (Arillo et al., 1981, Russo and Thurston, 1991).

Seabass fish farms in flow-through system usually operate at fish loading density of $50 \mathrm{~kg} \mathrm{~m}^{-3}$ (Lemarié et al., 1998). In that condition, ammonia concentrations never exceed $1.2 \mathrm{mg} \mathrm{l}^{-1} \mathrm{TAN}$ 
(0.05 mg l'-1 UIA-N) (Dosdat et al., 1996; Lemarié et al., 1998). Therefore, in those rearing conditions, the effects of ammonia on fish growth would remain low and would be economically acceptable. When using recirculating systems, ammonia levels can easily reach 10 to $15 \mathrm{mg} \mathrm{l}^{-1}$ TAN, which are usually considered as the upper allowable limits by the industry (Blancheton, personal communication). Nevertheless, in those systems the $\mathrm{pH}$ continuously decreases due to the build up of $\mathrm{CO}_{2}$ from fish and of $\mathrm{H}^{+}$from the nitrifying bacteria (Covès and Gasset, 1994). Optimal pH in seabass appeared to be 7.0 (Lemarié et al., 2000). In these conditions, UIA-N would amount at the most $0.1 \mathrm{mg} \mathrm{l}^{-1}$, which would result in a very slight growth reduction (Figure 2) and would be below the concentration of no-observable effect. Nevertheless, considering that UIA-N and $\mathrm{NH}_{4}^{+}$are more toxic at low $\mathrm{pH}$ and that ammonia toxicity is mainly due to UIA, safe ammonia levels in those systems have to be re-assessed.

Blood plasma TAN concentrations were positively correlated to ambient ammonia levels, as previously described in freshwater and seawater species (Arillo et al., 1981; Person-Le Ruyet et al., 1995, 1997a,b; Knoph and Thorud, 1996). In all ammonia exposed groups, they remain lower than the external TAN concentration in water (iso concentration was $6.4 \mathrm{mg} \mathrm{l}^{-1} \mathrm{TAN}$ ). The coefficient of the linear regression between plasma and ambient TAN (0.48) was close to the ones ((0.49-0.63)) reported by Person-Le Ruyet et al. (1997) in turbot in shorter term experiments (28-42 days), indicating that seabass can support ammonia in the long-term in the same way. The seabass appeared to adapt to a 3-fold increase in plasma TAN, relative to controls, without any mortality, but growth seemed to be significantly affected by plasma TAN concentrations over $8 \mathrm{mg} \mathrm{l}^{-1} \mathrm{TAN}$. This threshold level seems to be higher in turbot when it has 
been reported to be $10 \mathrm{mg} \mathrm{l}^{-1}$ plasma TAN (Person-Le Ruyet and Bœuf, 1998). This is consistent with a higher sensitivity of seabass to ammonia.

Oxygen consumption in fasted fish was correlated to ammonia level in ambient seawater. Higher $\mathrm{O}_{2}$ consumption in ammonia-exposed groups is related to the observed hyper-ventilation. These results are in agreement with observations by Knoph (1996). $\mathrm{MO}_{2}$ increased with ammonia level and was 1.5 times higher than the control under the highest ammonia concentration. The oxygen consumption by the control fish was similar to the value given by Lemarié et al. (1992).

To conclude, more information are required to determine precisely safe levels for ammonia in sea bass and particularly their interactions with other environmental factors, specially when $\mathrm{pH}$ and $\mathrm{CO}_{2}$ conditions vary. The reduced growth of seabass observed when ammonia concentration increases, specially in recirculating systems (Blancheton et al., 2001), can be attributed not only to UIA-N concentration but to other parameters as $\mathrm{pH}, \mathrm{CO}_{2}$ or $\mathrm{NO}_{2}{ }^{-}$which could act in synergy and affect growth potential. Further, investigations on the physiological mechanisms involved in long-term toxicity and adaptation to ammonia are still required.

\section{Acknowledgements}

The authors would like to thank J. Melard and J. P. Blancheton for their assistance. 


\section{References}

Alabaster, J.S., Shurben, D.G., Knowles, G., 1979. The effects of dissolved oxygen and salinity on the toxicity of ammonia to smolts of salmon, Salmo salar (L.). J. Fish Biol. 15, 705712.

Alderson, R., 1979. The effect of ammonia on the growth of juvenile Dover sole, Solea solea (L.) and turbot, Scophthalmus maximus (L.). Aquaculture 17, 291-309.

Arillo, A., Margiocco, C., Melodia, F., Mesi, P., 1981. Effects of ammonia on liver lysosomal functionality in Salmo gairdneri Rich. J. Exp. Zool. 218, 321-326.

Blancheton, J.P., Gaumet, F., Gasset, E., Conte, M., 2001. Recirculation systems for seabass farming from laboratory to industrial pilot scale : biologic-economic results. International Workshop on Better use of Water, Nutrient and Space, Trondheim, Norway, August 7, 2001. European Aquaculture Society (abstract).

Boujard, T., Dugy, X., Genner, D., Gosset, C., Grig, C., 1992. Description of a modular, low cost, eater meter for the study of feeding behaviour and food preferences in fish. Physiol. Behav. 52, 1101-1106. 
Bower, C.E., Bidwell, J.P., 1978. Ionization of ammonia in seawater: effects of temperature, $\mathrm{pH}$, and salinity. J. Fish. Res. Board Can. 35, 1012-1016.

Bower, C.E., Holm-Hansen, T., 1980. A salicylate-hypochlorite method for determining ammonia in seawater. Can. J. Fish. Aquat. Sci. 37, 794-798.

Colt, J., Tchobanoglous, G., 1978. Chronic exposure of channel catfish, Ictalurus punctatus, to ammonia : effects on growth and survival. Aquaculture 15, 353-372.

Covès, D., Dewavrin, G., Breuil, G., Devauchelle, N., 1991. Culture of sea bass (Dicentrarchus labrax L.). In : Handbook of Mariculture, Vol. 2, Finfish Aquaculture, (ed.) J. P. Mc Vey, CRC Press, Florida, 3-20.

Covès, D., Gasset., E., 1994. Super Intensive Seabass (Dicentrarchus labrax) Fingerling Production in Closed System - Oxygen Supply and Failure Integrated Management and Water Quality Evaluation. In : Kestemont P., Muir J., Sevila F. and P. Williot (eds.), Actes du Colloque « Bordeaux Aquaculture 94 ». Measures For Success. CEMAGREF Editions, 53-56.

Dosdat, A., Gaumet, F., Chartois, H., 1992. Marine aquaculture effluent monitoring : methodological approach to the evaluation of nitrogen and phosphorus excretion by fish. Aquacult. Eng. 14, 59-84. 
Dosdat, A., Servais, F, Métailler, R., Huelvan, C., Desbruyères, E., 1996. Comparison of nitrogenous losses in five teleost fish spacies. Aquaculture 141, 107-127.

Fivelstad, S., Schwarz, J., Stromsnes, H., 1995. Sublethal effects and safe levels of ammonia in seawater for Atlantic salmon postmolts (Salmo salar L.). Aquacult. Eng. 14, 271-280.

Forster, R.P., Goldstein, L., 1969. Formation of excretory products. In Fish Physiology, Vol. 1; pp. 313-350. Hoar, W.S., and Randall, D.J., eds., Academic Press, New York

Handy, R.D., Poxton, M.G., 1993. Nitrogen pollution in mariculture: toxicity and excretion of nitrogenous compounds by marine fish. Fish Biol. Fish. 3, 205-241.

Haywood, G.P., 1983. Ammonia toxicity in teleost fish: a review. Can. Tech. Rep. Fish. Aquat. Sci. 1177, 1-35.

Johansson O., Wedborg, M., 1980. The ammonia-ammonium equilibrium in seawater at temperatures between 5 and $25^{\circ} \mathrm{C}$. J. Solut. Chem. 9, 37-44.

Knoph M.B. 1996. Gill ventilation frequency and mortality of Atlantic salmon (Salmo salar L. ) exposed to high ammonia levels in seawater. Wat. Res. 30, 837-842. 
Knoph M., Thorud, K., 1996. Toxicity of ammonia to Atlantic salmon (Salmo salar L.) in seawater.- Effects on plasma osmolarity, ion, ammonia, urea and glucose levels and heamatologic parameters. Comp. Biochem. Physiol. 113, 375-381.

Lemarié, G., Dutto, G., Le Roux, A., Lemoalle, J., Maxime, V., Person-Le Ruyet, J, 2000. Long term effects of $\mathrm{pH}$ and carbon dioxide on growth and feed efficiency in European seabass. In : Responsible aquaculture in the new millenium, Conference AQUA 2000, Nice, France, May 2-6 2000. European Aquaculture Society Special Publication 28, p484 (Abstract).

Lemarié, G., Gasset, E., Cam, D., de La Fonchais, E., 1992. Modélisation de la consommation en oxygène du loup (Dicentrarchus labrax L.) et de la daurade (Sparus auratus L.). Ichtyophysiol. Acta 15, 55-68.

Lemarié, G., Martin, J.L., Dutto, G., Garidou, C., 1998. Nitrogenous and phosphorous waste production in a flow-through land-based farm of European seabass (Dicentrarchus labrax). Aquat. Living Resour. 11, 247-254.

Montfort, P., Montoliu, C., Hermenegildo, C., Munoz, M.D., Felipo, V., 2000. Differential effects of acute and chronic hyperammoniemia on signal transduction pathways associated to NMDA receptors. Neurochemistry International 37, 249-253. 
Peres, H., Oliva-Teles, A., 1999. Effects of dietary lipid level on growth performance and feed utilization by sea bass juveniles (Dicentrarchus labrax). Aquaculture 179, 325-334.

Person-Le Ruyet, J., Bœuf, G., 1998. L’azote ammoniacal, un toxique potentiel en élevage de poissons: le cas du turbot. Bull. Fr. Pêche Piscic. 350-351, 393-412.

Person-Le Ruyet, J., Bœuf, G., Zambonino-Infante, J., Helgason, S., Le Roux, A., 1998. Short term physiological changes in turbot and seabream juveniles exposed to exogenous ammonia. Comp. Biochem. Physiol. 119A, 511-518.

Person-Le Ruyet, J., Chartois, H., Quemener, L., 1995. Comparative acute ammonia toxicity in marine fish and plasma ammonia response. Aquaculture 136, 181-194.

Person-Le Ruyet, J., Delbard, C., Chartois, H., Le Delliou, H., 1997b. Toxicity of ammonia to turbot juveniles: 1-effects on survival, growth and food utilisation. Aquat. Living Resour. 10, 307-314.

Person-Le Ruyet, J., Galland R., Le Roux A., Chartois, H., 1997a. Chronic ammonia toxicity in juvenile turbot (Scophthalmus maximus). Aquaculture 154, 155-171.

Person-Le Ruyet, J., Lemarié, G., Bœuf, G., 2000. Control of somatic growth in the European seabsss by environmental factors. In : Responsible aquaculture in the new millenium, 
Conference AQUA 2000, Nice, France, May 2-6 2000. European Aquaculture Society Special Publication 28, p557 (Abstract).

Pichavant K., Person-Le Ruyet, J., Lebayon, N., Sevère, A., Le Roux, A., Bœuf, G., 2001. Comparative effects of long-term hypoxia on growth, feeding and oxygen consumption in juvenile turbot and European sea bass. J. Fish Biol. 59, 875-883.

Quéméner, L., Gaignon J. L., Kaushik S. J. , 1999. Courbes de croissance et relation taille masse corporelle chez quelques poissons. In : Nutrition et alimentation des poissons et des crustacés, Guillaume J., Kaushik S., Bergot P. and Métailler R. (eds). INRA Editions, 429440.

Ruffier, P.J., Boyle, W.C., Kleinschmidt, J.K., 1981. Short-term acute bioassays to evaluate ammonia toxicity and effluents standards. J. Water Poll. Contr. Fed. 53, 367-377.

Russo, R.C., Thurston, R.V., 1991. Toxicity of ammonia, nitrite and nitrate to fishes. In : E. Brune and J.R. Tomasso (Eds.), Aquaculture and water quality., WAS Publication, 58-89.

Thurston, R.V., Philipps G.R., Russo, R.C., 1981. Increased toxicity of ammonia to rainbow trout (S. gairdneri) resulting from reduced concentrations of dissolved oxygen. Can. J. Fish. Aqua. Sci. 38, 983-988. 
Tomasso, J.R., 1994. Toxicity of nitrogenous wastes to aquaculture animals. Rev. Fish. Sci. 2, 291-314.

Tudor, M., Katavic, I., Marsic-Lucic, J., 1994. Acute toxicity of ammonia to juvenile sea bass (Dicentrarchus labrax L.) at different aeration levels. Aquaculture 128, 89-95.

Wajsbrot, N., Gasith, A., Diamant, A., Popper, D.M., 1993. Chronic toxicity of ammonia to juvenile gilthead seabream Sparus aurata and related histopathological effects. J. Fish Biol. 43, 321-328.

Wang, Y., Walsh, P.J., 2000. High ammonia tolerance in fish of the family Batrachoididae (Toadfish and Midshipmen). Aquatic Toxicology 50, 205-219.

Whitfield, M., 1974. The hydrolysis of ammonium ions in sea-water. A theoretical study. J. Mar. Biol. Assoc. U.K., 54, 565-580.

Wood, C.J., 1993. Ammonia and urea metabolism and excretion. In : D.H. Evans (Editor), The Physiology of Fishes, 379-425.

Zar, J.H., 1984. Biostatiscal analysis. Prentice-Hall, Inc., Englewood Cliffs, New-Jersey; pp 718. 